\title{
Ф. Хёльшер
}

Констаниский университет

FernandeHoelscher@gmx.de

(Герлания, Констани)

\section{АЯКС И НЕОПТОЛЕМ В ИЗОБРАЗИТЕЛЬНОМ ИСКУССТВЕ: КАК ГРЕКИ ОСМЫСЛЯЛИ ЖЕСТОКОСТЬ СВОИХ ГЕРОЕВ}

\begin{abstract}
Аннотация. В статье рассматриваются два мифологических сюжета, связанных с Троянской войной: убийство Астианакса Неоптолемом и нападение Аякса на Кассандру, искавшую убежища у статуи городской богини Афины. Эти кощунственные действия повлекли за собой гнев богов, которые покарали возвращавшихся домой ахейцев. О том внимании, которое греки уделяли этим сюжетам, свидетельствует их отражение как в письменных источниках, так и в вазописи. Возникает вопрос об осмыслении греками жестокости Аякса и Неоптолема, которые не только не были прокляты, но и почитались как герои. Последнее выявляет отношение греков к нарушению героями границ дозволенного: ими восхищались не несмотря на их действия, а именно за них. Таким образом, современные моральные критерии для оценки этих сюжетов неприменимы. Автор статьи предпринимает попытку ответить на вопрос о причинах, побудивших вазописцев обратиться к этим сюжетам в начале $\mathrm{V}$ в. до. н. э., в период конфликта с персами.
\end{abstract}

Ключевье слова: "Разрушение Илиона», Аякс, Неоптолем, оценка трансгрессии, кощунство, божественная кара, культ героев, аттическая вазопись, гидрия мастера Клеофрада, грекоперсидские войны, Геродот и религиозная трансгрессия

Для иитирования: Хёльшер Ф. Аякс и Неоптолем в изобразительном искусстве: как греки осмысляли жестокость своих героев // Шаги/Steps. T. 6. № 2 . 2020. C. 130-143. DOI: 10.22394/2412-9410-2020-6-2-130-143.

Статья поступила в редакиию 15 октября 2019 г. Принято к печати 24 ноября 2019 г. 


\title{
AJAX AND Neoptolemos in the Visual ARTs: How THE GREeKS DEALT WITH THE ATROCITIES OF THEIR HEROES
}

\begin{abstract}
The article deals with the two sacrileges at the end of the Trojan war: that of Neoptolemos who killed Astyanax in a most brutal way and that of Ajax who dragged Kassandra away from the statue of the city goddess Athena with whom she had taken refuge. These sacrileges were not isolated heroic acts, but have to be seen in the reactions of the offended gods and the resulting consequences for all the Achaeans on their way home. In addition to written sources, vase painting around 500 B.C.E. can help us understand the concern of the Greeks for this topic. The question arises as to how the two sacrileges were evaluated in the assessment of the heroes since they were not damned for their brutality but instead honored in their home towns. This opens the view on transgression of heroes and warriors in a general way. They were admired despite and because of their transgression. Therefore modern moral criteria in the evaluation of scenes in Greek vase painting must be questioned. The article tries to give an answer to the question why the attic vase painters chose this subject in the years of the conflict with the Persians at the beginning of the $5^{\text {th }}$ century.
\end{abstract}

Keywords: Ilioupersis, Aiax, Neoptolemos, evaluation of transgression, sacrileges in warfare, punishment by the gods, hero cult, Attic Greek vase painting, Vivenzio-hydria, Persian wars, Herodotos and religious transgression

To cite this article: Hölscher, F. (2020). Ajax and Neoptolemos in the visual arts: How the Greeks dealt with the atrocities of their heroes. Shagi / Steps, 6(2), 130143. (In Russian). DOI: 10.22394/2412-9410-2020-6-2-130-143.

Received October 15, 2019

Accepted November 24, 2019 
$\mathrm{K}$ огда греки взяли Трою, они жестоко расправлялись с побежденными так обычно и происходит в завоеванном городе после многолетних изнурительных для обеих сторон сражений [West 2013: 163-243]. Но два поступка выходят далеко за рамки каких бы то ни было военных норм: Неоптолем, сын Ахилла, убивает царя Приама на алтаре Зевса Геркейского, а Аякс, преследуя Кассандру, силой отрывает ее от статуи Афины, покровительницы Трои ${ }^{1}$. Эти истории были известны из «Малой Илиады» и «Разрушения Илиона», но почему — и это главный вопрос - почему они так интересовали художников и в особенности вазописцев конца VI-V в. до н. э.? Возможно, мы найдем ответ, рассматривая те случаи, когда оба сюжета совмещаются в декоре одной вазы [Pipili 1997: 650-657]. На краснофигурной гидрии мастера Клеофрада (ок. 480 г. до н. э.) ${ }^{2}$ (илл. 1) Неоптолем уже готов убить Приама, который ищет спасения на алтаре Зевса Геркейского, покровителя домашнего очага. Царь Трои ранен - его голова и плечи в крови. Он закрывает голову руками, но это не жест защиты - это жест скорби по внуку Астианаксу, чей труп лежит у Приама на коленях. Жестокое убийство старика и ребенка на алтаре вместо жертвоприношения Зевсу, его алтарь, оскверненный человеческой кровью, - все это не позволяет усомниться в том, что царский дом Трои угасает навеки. На левом плече вазы рядом с Неоптолемом изображен Аякс, который нападает на Кассандру: левой рукой он тянет ее за волосы, а в правой держит угрожающе направленный на нее меч (илл. 2). Сама Кассандра припала к изваянию Афины: левой рукой она обнимает его жестом просительницы, а правую умоляюще протягивает к нападающему на нее Аяксу. Рядом с Кассандрой горюют троянки, и кажется, что даже пальма страдает.

Поступок Аякса стали трактовать как изнасилование Кассандры лишь в позднеэллинистической литературе, хотя эротические коннотации явно присутствуют и в ранних изображениях. Сам способ изображения Кассандры не оставляет сомнения в том, что художник хотел намекнуть на изнасилование: дочь царя, тесно связанная с Аполлоном и наделенная пророческим даром, не могла быть так скудно одета. Аякс поступил возмутительно и кощунственно - ведь Кассандра искала убежища у Афины, покровительницы Трои, и он своим поступком оскорбил богиню.

Как сообщают письменные источники, Аякс действовал с такой силой, что статуя опрокинулась с постамента. Уже в начале VI в. до н. э. Аякса изображали как преступника — и на рельефе бронзового щита, и в вазописи. И хотя художники не изображали здесь Афину на постаменте, совершенно очевидно, что это статуя, - ведь Кассандра обнимает ее, что было бы совершенно невозможно, будь то сама богиня. В последующие десятилетия соответствую-

\footnotetext{
${ }^{1}$ Cp. [Sciarma 2012]: к этим двум эпизодам автор добавляет третий - убийство Троила, совершенное Ахиллом в святилище Аполлона Тимбрейского.

${ }^{2}$ Cм.: [Simon, Hirmer 1976, pl. 128f.; Anderson 1997: 198, 217-245; Touchefeu 1981: 341 (44); Mangold 2000: 162, Kat. I32; Muth 2008: 580-582; Hölscher 2014: 167, Abb. 59]. О пальме см.: [Mangold 2000, 25f.]. Cp. [Hedreen 2001: 67-90]: в этой работе автор соотносит пальму с Аполлоном, который возвел троянские стены и алтарь Зевса; по мысли автора, Аполлон так тесно связан с троянцами, что его «символы» (треножник и пальма) присутствуют и в тех святилищах, где разворачиваются интересующие нас сцены, - в святилищах Афины и Зевса. В случае с Неоптолемом пальма может служить намеком на его грядущую смерть в Дельфах, хотя кара, его постигшая, никакого отношения к Аполлону не имеет.
} 


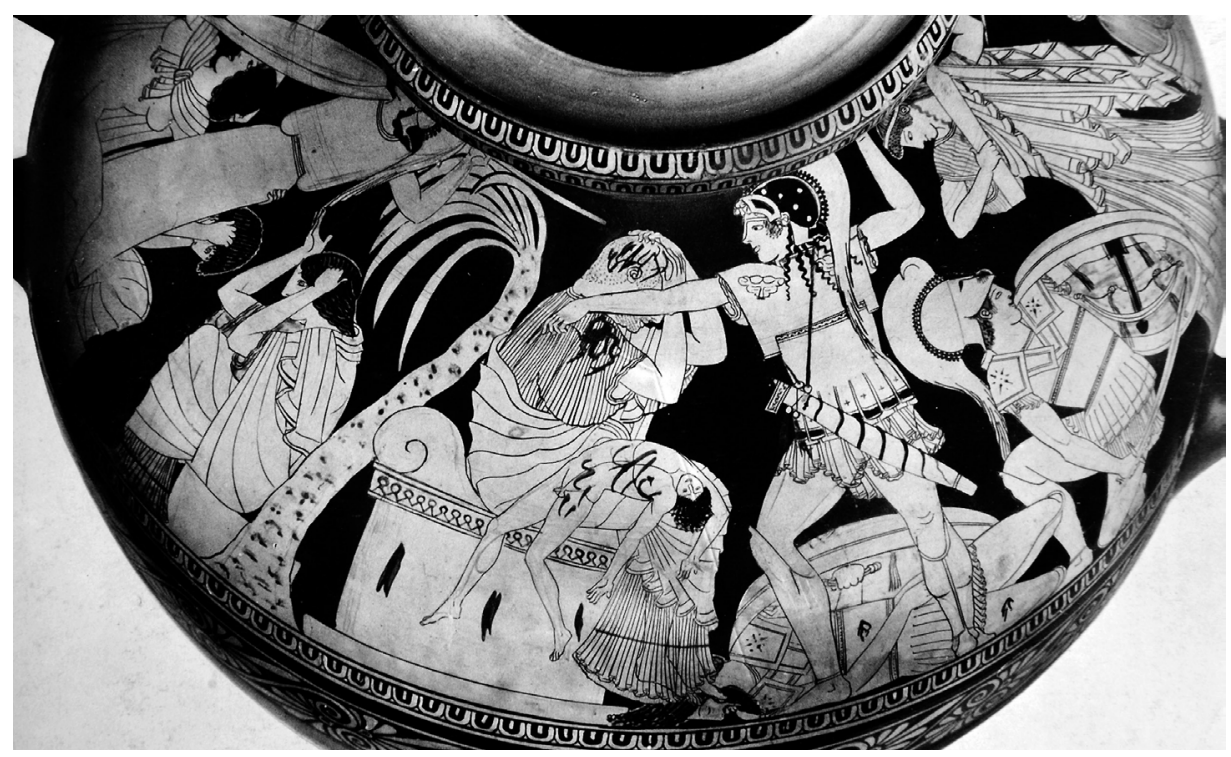

Илл. 1. Мастер Клеофрада. Гидрия. Ок. 480 г. до н. э. Национальный археологический музей (Неаполь). Н 2422 [Hölscher 2017: 97, Abb. 14]

Ill. 1. Kleophrades Painter. Hydria. About 480 BC National Archeological Museum of Naples. H 2422 [Hölscher 2017: 97, Abb. 14]

щую сцену часто изображали как противостояние Аякса и Афины, где Кассандра - маленькая девочка, которая на некоторых изображениях прячется за щитом богини ${ }^{3}$. В конце VI в. до н. э. художники стремились подчеркнуть, что Афина в этом эпизоде - статуя, а не сама богиня, и потому помещали ее на постамент, чтобы показать, что действие происходит в святилище, тем самым создавая равновесие с другой сценой, где Приама убивают на алтаре Зевса Геркейского. Художник Онесим на двух своих чашах тоже обозначил, что алтарь посвящен Зевсу Геркейскому ${ }^{4}$ (илл. 3). В данный период и сама статуя Афины - не просто каменное (или скорее деревянное) изваяние. Так, на лекифе из Гелы она посылает змею в наказание свирепому Аяксу. Этот Аякс сын Оилея, царя Локриды, его иногда называли Малым, чтобы отличить его от другого Аякса - Великого, сына Теламона. В нем воплотилась вся ярость греческих героев, его поступки совершаются как бы в помутнении рассудка, вне границ sophrosyne и самообладания [West 2013: 223-243].

${ }^{3}$ Об этих изображениях см.: [Hölscher 2017: 90-102].

${ }^{4}$ О килике Онесима см.: [Giuliani 2003: 203-214, Abb. 43 ([Зевсу] Оградному)], cp. Vatikan/Berlin 2280/1: [Touchefeu 1984: 932 (16); Giuliani, Heilmeyer 1991: 49, Abb. 1; Mangold 2000: 161, I 27 (Dios Hiero[n] и temenos)]. См. также: [Hölscher 2017: 95f., Abb. 13; Anderson 1997: 210, 220]. 


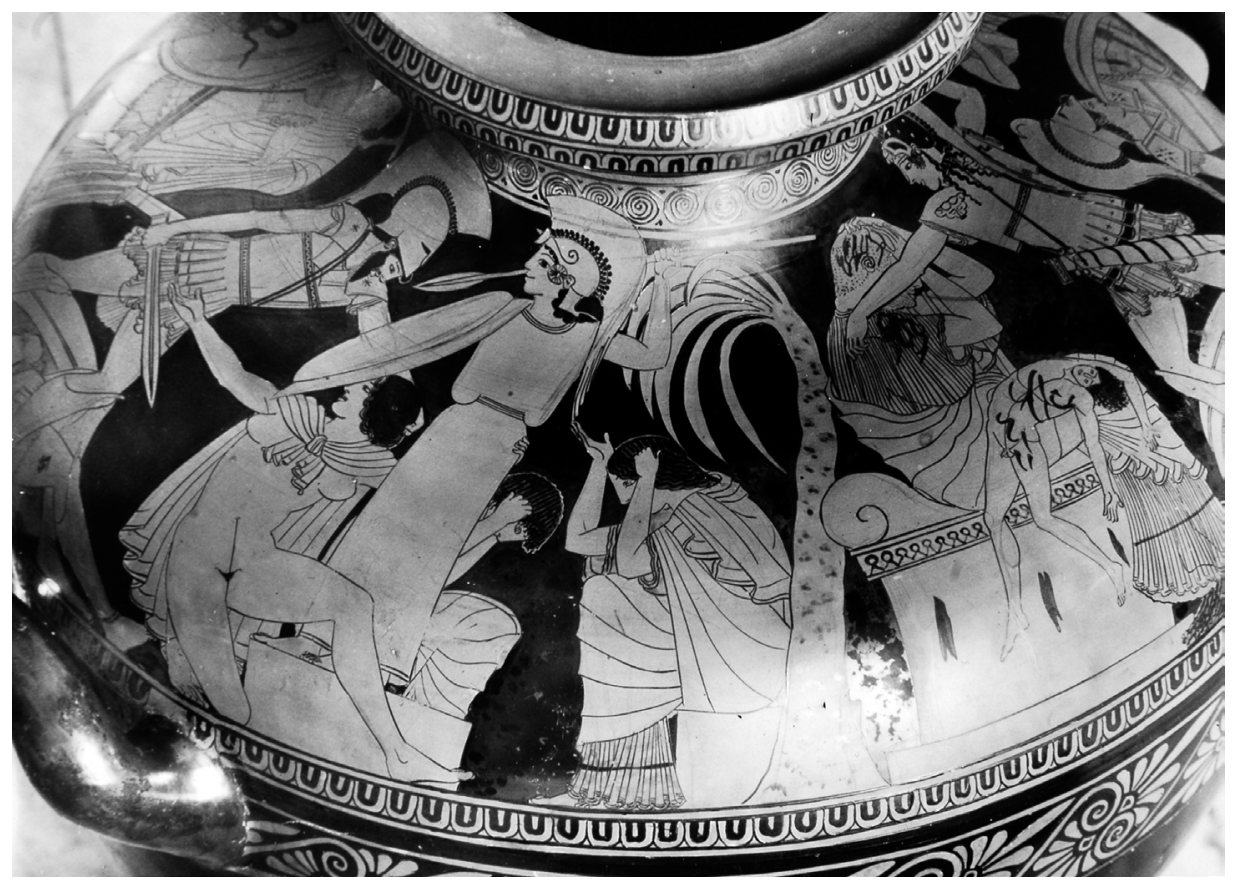

Илл. 2. Мастер Клеофрада. Гидрия. Ок. 480 г. до н. э. Наииональныий археологический музей (Неаполь). Н 2422 [Simon, Hirmer 1976, pl. 128]

Ill. 2. Kleophrades Painter. Hydria. About 480 BC National Archeological Museum of Naples. H 2422 [Simon, Hirmer 1976, pl. 128 ]

Злодеяние Неоптолема, убивающего Приама на алтаре, - тоже распространенный изобразительный сюжет с самого начала VI в. до н. э. [Mangold 2000: 13-33]. Но нас интересуют те случаи, когда обоих персонажей в их hybris представляют вместе. В случаях, подобных изображению на гидрии мастера Клеофрада, художники явно не стремятся показать героев как таковых, их интересует более широкая тема - тема войны. Бо́льшая часть сосудов, где фигурируют и Аякс, и Неоптолем, датируется рубежом VI и V вв. до н. э. и первыми десятилетиями $\mathrm{V}$ в. до н. э. На чаше художника Онесима (илл. 3) из собрания музея Вилла Джулия в Риме (в настоящее время находится в Национальном музее Черите, Черветери) (ок. 490 г. до н. э.) мы видим девять разных сцен из «Разрушения Илиона», но два интересующих нас злодейских поступка строго коррелируют друг с другом: на тондо внутри килика Неоптолем убивает Приама, причем художник утрирует его ярость: в качестве орудия убийства Неоптолем использует тело Астианакса внук становится орудием убийства деда ${ }^{5}$. Этот мотив явно был изобретением ва-

${ }^{5}$ CM.: [Pipili 1997: 652 (7); Mangold 2000: 161, Kat. I28; Giuliani 2003: 203-214; Muth 2008: 556-559, Abb. 400]. 


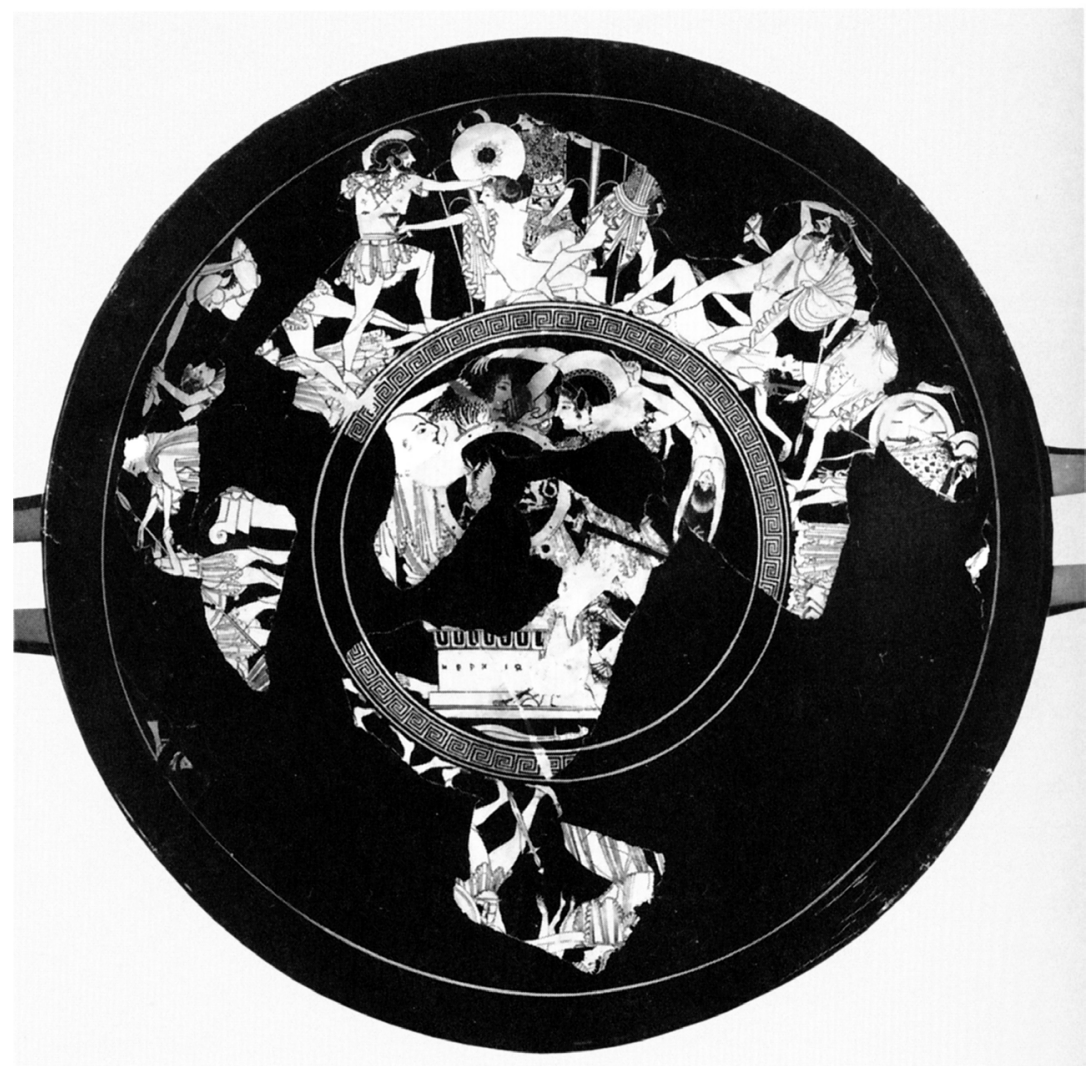

Илл. 3. Онесим. Чаша. 500-490 г2. до н. э.

Национальный этрусский музей (Вилла Дюсулия, Рим), № 121110 (в настоящее время в Национальном музее Черите, Черветери)

[Giuliani 2003: 213, Abb. 43]

\author{
Ill. 3. Onesimos. Cup. 500-490 BC \\ National Etruscan Museum Villa Giulia (Rome), No. 121110 \\ (now in the National Museum of Cerveteri) \\ [Giuliani 2003: 213, Abb. 43]
}

зописцев, потому что в письменных источниках Астианакса сбрасывают с городской стены. Сцена похищения Кассандры изображена на внутренней стенке килика по той же оси. Здесь Кассандра опять обнажена, беззащитна и в отчаянии обвивает рукой статую. Спустя 20 лет художник снова изображает две эти сцены параллельно (илл. 4): два нападающих, две жертвы, каждая из которых протягивает руку, как будто в надежде на помощь в безнадежной ситуации [Mangold 2000: 163 Kat. I36].

В чем состоит основной смысл этой параллели? В том ли, что художника восхищала способность героев выйти за рамки допустимого? Или, наоборот, его задача состояла в том, чтобы продемонстрировать кровавую ярость Неоптолема и сексуальную распущенность Аякса? С моей точки зрения, здесь 


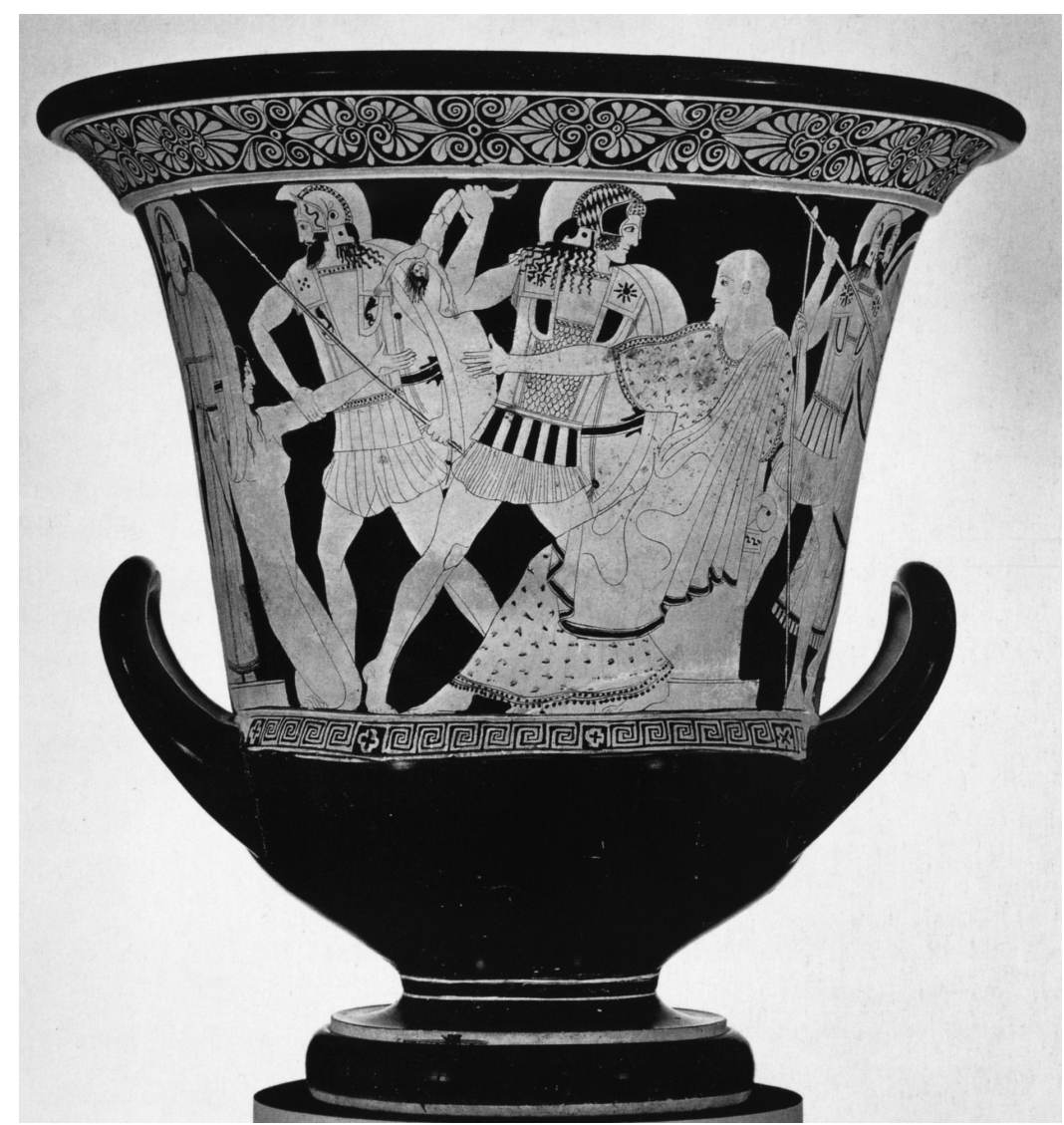

Илл. 4. Мастер из Альтамурыл. Бостонский кратер. Ок. 470 г. до н. э. Музей изящных искусств (Бостон), № 59.178 [Mangold 2000: 52, Abb. 30]

III. 4. Altamura Painter. Krater. Boston. About 470 BC Museum of Fine Arts (Boston). No. 59.178

[Mangold 2000: 52, Abb. 30]

нужно соблюдать особую осторожность и не подходить к античным образам с нашими нравственными мерками. Некоторые исследователи уже показали, что блеск славы и нарушение границ дозволенного - это две стороны одной медали. Возможно, греческие герои, подобные Аяксу, Неоптолему и в особенности Ахиллу, и не вызывали бы восхищения и желания подражать, если бы они, преисполнившись самоуверенности, не преступали этой черты ${ }^{6}$.

Но есть еще один аспект - вопрос о божественном возмездии, которое постигает таких героев [Anderson 2001: 31f, сp. 75-81]; см. также: [Fisher 1992: 28f]. В интересующих нас изображениях месть богов не является непосред-

${ }^{6}$ CM.: [Trampedach 2005; Gehrke 2010; von den Hoff 2010: 225-246; Giuliani 2010; Hölscher 2019: 60-82]. 
ственным предметом повествования, но некоторые детали, например изображение пальмы в сцене с Неоптолемом на гидрии мастера Клеофрада, могут служить намеком - ведь кара настигла Неоптолема именно в святилище Аполлона в Дельфах [Hedreen 2001: 67-90] ${ }^{7}$. Возможно, намеком на гнев богини является и сама поза статуи Афины на чаше Онесима — ведь сразу после надругательства над Кассандрой Афина, как нам это описывает Алкей [Hölscher 2017: 92, Anm. 117], устремилась к морю, чтобы устроить бурю и погубить ахейцев.

В самом деле, месть Афины была направлена не только на Аякса: богиня была разгневана вдвойне - и кощунством героя, и поведением ахейцев, которые не наказали Аякса, как он того заслуживал. По-видимому, он дал клятву ахейским вождям, и те воздержались от наказания. Об этом рассказывает Павсаний, описывая картину, созданную Полигнотом около 450 г. до н. э. в лесхе книдян в Дельфах:

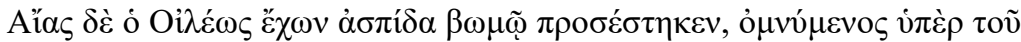

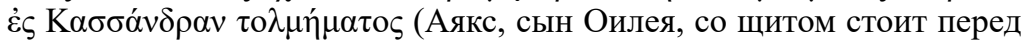
жертвенником и приносит клятву из-за своего дерзкого покушения на Кассандру — Павсаний Х.26,3; пер. С. П. Кондратьева).

О содержании клятвы не сказано ничего, но она могла быть связана с храмовой службой в святилище Афины в Трое. Как сообщают античные авторы, каждый год две локрийские девушки должны были нести службу в этом храме в качестве платы за кощунство, совершенное Аяксом. Этот обычай сохранялся вплоть до римской эпохи [Rösler 1987]. Но Афина клятвой Аякса явно не удовлетворилась: она не приняла ее и не дала ахейцам покинуть Трою. Тогда они, ощутив, наконец, ярость богини, решили побить Аякса камнями, но тот ушел от наказания, по иронии судьбы найдя убежище у алтаря самой Афины. Эта ситуация трагична, потому что безысходна: ахейцы могли умиротворить Афину, лишь опять нарушив священный закон неприкосновенности того, кто ищет защиты у алтаря бога. Гнев богини, еще более яростный из-за того, что все эти годы она помогала ахейцам сражаться, ясно виден в «Троянках» Еврипида, в диалоге Афины с Посейдоном (80-86):

Едва домой из Трои корабли

Направятся, и дождь и град на них

Безмерные посыплются, и неба

Им черное пошлет Кронид дыханье,

80 А мне перун вручит, и, поразив

Ахейские суда, испепелю их...

Ты ж, бог, заставь Эгейские пути

Греметь от треволнений и в пучину

Открой водовороты да наполни

Их трупами земли Евбейской: п у сть

Научатся мои чертоги чтить,

Да и других бессмертных не порочить.

(Пер. И. Ф. Анненского)

${ }^{7}$ См. прим. 2. 


\section{У Аполлодора в Эпитоме (VI.5-6) читаем:}

Агамемнон, принеся жертву, отплыл и причалил к Тенедосу; Неоптолема же появившаяся Фетида убедила подождать еще два дня и принести жертву, и тот остался. Другие, выплыв в открытое море, попали в бурю у Теноса, ибо Афина упросила Зевса наслать бурю на эллинов. Многие корабли эллинов пошли ко дну. (6) Афина метнула перун в корабль Аякса. Судно разрушилось, сам же Аякс спасся, уцепившись за скалу. При этом Аякс сказал, что спасение пришло к нему против воли Афины. Тогда Посейдон ударил трезубцем в скалу и расколол ее, Аякс же упал в море и погиб. Тело его, выброшенное волнами, предала погребению Фетида на Миконосе (пер. В. Г. Боруховича).

Неоптолем послушался совета своей бабушки Фетиды, остальные же ахейцы повели себя своевольно, и их корабли затонули. Более того, Аякс хвастался, что сумел спастись вопреки гневу Афины: это определило его судьбу как человека вдвойне нечестивого. Сравнение высокомерного Аякса с Неоптолемом - явно в пользу последнего: он был вынужден уничтожить царский дом, и потому следом за Гектором настал черед его отца и его сына - иначе угроза троянского реванша продолжала бы нависать над ахейцами. Такова логика войны. Но поведение Аякса не имело никакого отношения к войне как таковой. Он был нечестив и высокомерен - отсюда его ранняя и бесславная смерть, посланная Афиной при содействии Посейдона.

Геродот, с особым вниманием относившийся к нарушениям границ дозволенного в религиозной сфере, приводит исторические примеры поступков, последствия которых воспринимались как месть богов. Это означает, что в V в. до н. э. греки понимали: нарушение границ дозволенного - не привилегия варваров, на это способны и сильные, могущественные греки. И существует множество примеров исторического времени, когда боги карают за кощунство. Один из них мы находим у Геродота (VII.133). События, о которых здесь идет речь, относятся приблизительно к тому же времени, что и интересующие нас изображения:

В Афины же и в Спарту Ксеркс не отправил глашатая с требованием земли [и воды], и вот по какой причине. Когда Дарий прежде отправил туда послов, требуя покорности, то афиняне сбросили их в пропасть, а спартанцы - в колодец и велели им оттуда принести [царю] землю и воду. Поэтому-то Ксеркс теперь и не послал к ним глашатаев с требованием покорности. Какое несчастье постигло афинян за их поступок, я не могу сказать, кроме того, что их земля и сам город были разорены. Впрочем, мне думается, опустошение [Аттики] произошло не из-за этого ${ }^{8}$ (пер. Г. А. Стратановского).

${ }^{8} \mathrm{O}$ несоответствии кощунственного поступка афинян и такого наказания см.: [Scardino 2007: 206, n. 370]. У Павсания (III. 12, 7) та же история связывается с гневом Талфибия. 
Далее Геродот рассуждает о том, какие последствия имело убийство глашатаев для спартанцев и как они пытались искупить вину. Геродот понимал, что на афинян боги тоже должны были гневаться, но не знал, как именно проявился их гнев.

И Аякс, и Неоптолем ощущали этот гнев, но следует иметь в виду, что с моральной точки зрения они не воспринимались как агрессоры, и даже если их изображения имеют обличительный характер, последнее слово - не за ними. Память Неоптолема не была проклята - его чтили в Дельфах, где он мог «блюсти чин многожертвенных шествий» (Пиндар, VII Немейская ода, 46-47). У Пиндара говорится о том, что Неоптолем умер в святилище Аполлона более или менее случайно - или в ссоре (VII Немейская ода, 34-47), или от руки самого Аполлона (Пеан 6) 9 . В немейской версии (ок. 485 г. до н. э.) Пиндар рассказывает о благом исходе судьбы Неоптолема - он не подвергся ни наказанию, ни порицанию за военные преступления, хотя все знали о том, как он вел себя. То же касается и Аякса: он преступил границу дозволенного, но при этом его почитали как героя, запечатлев его образ на монетах в Локрах Опунтских. Более того, «когда локрийцы узнали о его смерти, они оплакивали его и носили черные одежды целый год, и потом каждый год они нагружали судно богатыми дарами, ставили на нем черный парус, потом поджигали судно и так пускали его в море, чтобы он сгорел на воде - как жертвоприношение утонувшему герою» (Иоанн Цец. Схолии к Ликофрону, 365). В историческое время для Аякса всегда оставляли место в боевом строю - его сила и храбрость служили воинам примером для подражания (Павсаний, III.19, 11; Конон. Повествования, 18). Посмертная судьба этих героев свидетельствует о том, что их почитали, что их энергией и силой восхищались, потому что и несмотря на то что их самообладание не было безупречным. И в этом проявляется важнейшая особенность представления афинян исторической эпохи о самих себе.

Двойственность всех событий, происходивших в хаосе Троянской войны, выдвинута на первый план и в изображении на гидрии Вивенцио (илл. 5). Две параллельные сцены преступлений Аякса и Неоптолема окружены иными сценами разрушенной Трои, уже с положительными коннотациями: Эней несет на плече старого отца, за ним следует его сын Асканий - эта сцена составляет контраст происходящему в доме Приама; сыновья Тезея, Демофон и Акамант, спасают свою бабушку Эфру, уводя ее домой ${ }^{10}$.

Изображения с несколькими троянскими сценами появляются около 500 г. до н. э. и в начале V в. до н. э., когда был разрушен Милет, а Фриних поставил свою трагедию «Взятие Милета» (492 г. до н. э). На более поздних художников могло повлиять потрясение, испытанное греками в 480 г. до н. э., когда персы вторглись в Аттику и разорили Афины. Художники не иллюстрировали со-

${ }^{9}$ Наличие двух версий этой истории не следует рассматривать как попытку ее скорректировать - это две истории, где акценты расставлены по-разному [Hölscher 2002: 114, 152]. Немейская версия прославляет одного из Эакидов, а пифийская отсылает к обычному толкованию смерти Неоптолема - это месть Аполлона. Согласно Павсанию (IV. 17, 4), если зло, сделанное человеку, постигает самого злодея, это называется «Неоптолемовой карой». Об истории Неоптолема у Софокла и Еврипида см.: [Vlachogianni 2018: 10-12].

${ }^{10} \mathrm{O}$ том, что эта группа сцен должна была, по замыслу художника, составить контраст сценам насилия, см.: [Recke 2002: 231]. 


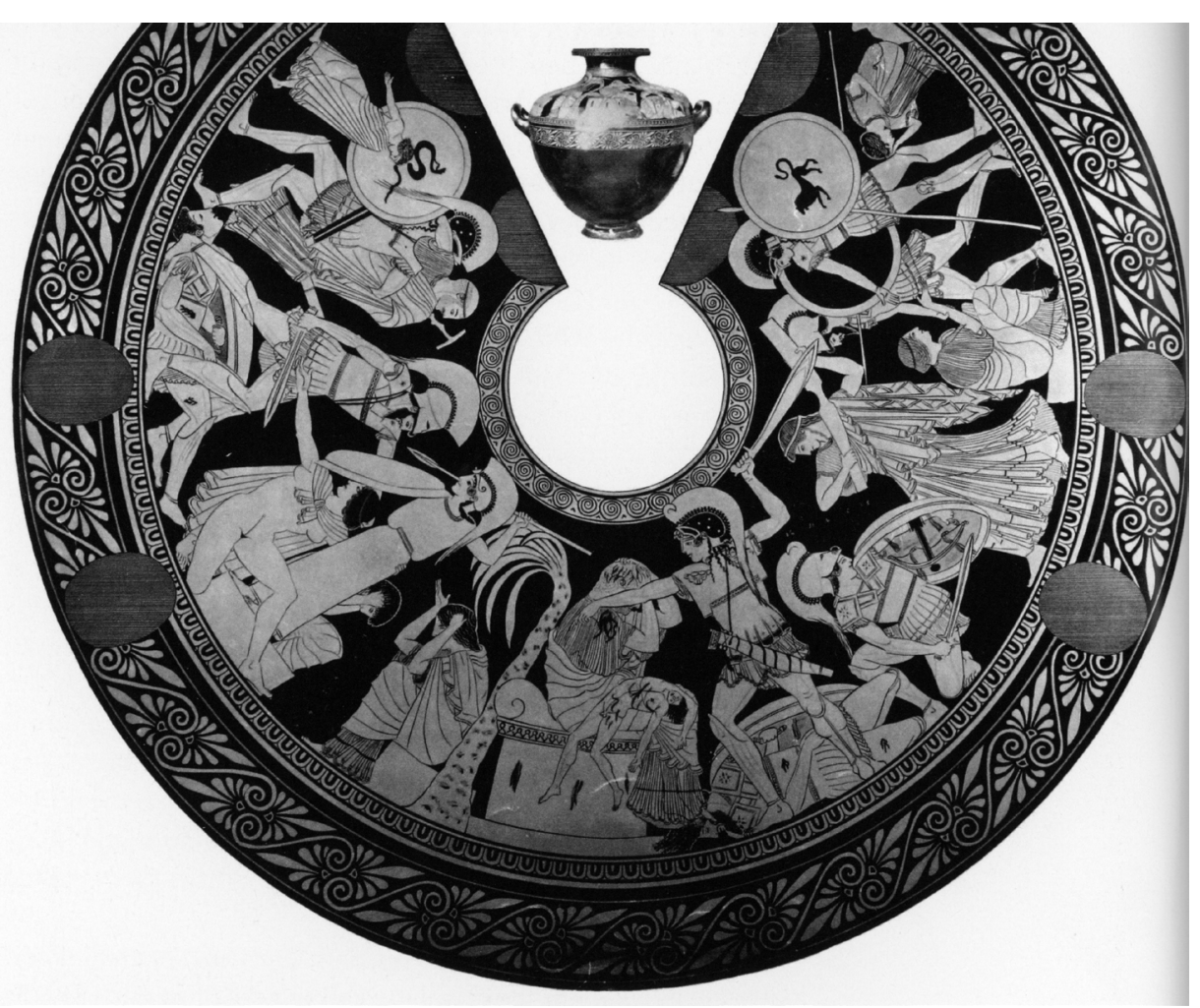

Илл. 5. Мастер Клеофрада. Гидрия. Ок. 480 г. до н. э. Национальный археологический музей (Неаполь). № 2422 [Giuliani 2003: 219, Abb. 45b]

IIl. 5. Kleophrades Painter. Hydria. About 480 BC National Archeological Museum of Naples. No. 2422

[Giuliani 2003: 219, Abb. 45b]

временных событий, но именно война была тем психологическим фоном, на котором создавались изображения, - война со всей ее раздвоенностью, где одни герои движимы яростью (Неоптолем и Аякс), а другие - милосердием (Эней и сыновья Тезея).

В сцене с Кассандрой ключевым персонажем является Афина - с одной стороны, она защищает Кассандру, с другой - преследует Аякса за кощунство, и потому тот факт, что два из небольшой группы сосудов, где совмещены несколько троянских сцен, были найдены на Акрополе, едва ли можно считать случайностью ${ }^{11}$. Эти приношения Афине были сделаны не ради того, чтобы обвинить героев, но ради того, чтобы показать, что Афина была не просто вовлечена в ратные дела ахейцев - ее беспокоили кощунственные поступки, неразрывно связанные с жестокостью военного времени. Недавние известия

${ }^{11}$ См.: [Mangold 2000: 161, I29, 163, I38]; cp. также [Ibid: 172, II 50 (только Аякс)]. 
о событиях в разрушенном Милете перевернули сознание афинян. А трагедия Фриниха «Взятие Милета» потрясла зрителей до такой степени, что ее запретили после первой постановки, — вызванные ею переживания сочли вредными для афинян. Мы не знаем, какие чувства вызывали изображения на вазах. Возможно, глядя на события мифологического прошлого, люди легче переносили настоящее, понимая, что жестокость могли проявлять и те герои, которых они так глубоко чтили.

\section{Пер. с англ. О. Л. Ахуновой (Левинской)}

\section{Литература}

Anderson 1997 - Anderson M. $J$. The fall of Troy in early Greek poetry and art. Oxford: Clarendon Press, 1997.

Fisher 1992 - Fisher N. R. E. Hybris: A study in the values of honour and shame in Ancient Greece. Warminster: Aris \& Phillips, 1992.

Gehrke 2010 - Gehrke H.-J. Der zwiespältige Held // Helden wie sie: Übermensch — Vorbild - Kultfigur in der griechischen Antike. Beiträge zu einem altertumswissenschaftlichen Kolloquium in Wien, 2.-4. Februar 2007 / Hrsg. M. Meyer, R. von den Hoff. Freiburg: Rombach, 2010. S. 39-54.

Giuliani 2003 - Giuliani L. Bild und Mythos. Geschichte der Bilderzählung in der griechischen Kunst. München: C. H. Beck, 2003.

Giuliani 2010 - Giuliani L. Helden-Hybris // Helden wie sie: Übermensch - Vorbild - Kultfigur in der griechischen Antike. Beiträge zu einem altertumswissenschaftlichen Kolloquium in Wien, 2.-4. Februar 2007 / Hrsg. M. Meyer, R. von den Hoff. Freiburg: Rombach, 2010. S. 203-214. Freiburg: Rombach, 2010.

Giuliani, Heilmeyer 1991 - Euphronios der Maler: eine Ausstellung in der Sonderausstellungshalle der Staatliche Museen Preussischer Kulturbesitz, Berlin-Dahlem 20.3.-26.5.1991 / Hrsg. L. Giuliani, W.-D. Heilmeyer. Mailand: Fabbri, 1991.

Hedreen 2001 - Hedreen G. M. Capturing Troy: The narrative functions of landscape in archaic and early classical Greek art. Ann Arbor: Univ. of Michigan Press, 2001.

von den Hoff 2005 - Hoff R. von den. “Achill, das Vieh?” Zur Problematisierung transgressiver Gewalt in klassischen Vasenbildern // Die andere Seite der Klassik. Gewalt im 5. und 4. Jahrhundert v. Chr. / Hrsg. G. Fischer, S. Moraw. Stuttgart: Franz Steiner Verlag, 2005. S. 225-246.

Hölscher 2002 -Pindar. Siegeslieder / Übersetzt von Uvo Hölscher. München: C. H. Beck, 2002.

Hölscher 2014 - Hölscher T. Im Bild noch lebendiger als in Wirklichkeit: Bildwerke, Lebewesen und Dinge im antiken Griechenland // Ding und Mensch in der Antike. Gegenwart und Vergegenwärtigung / Hrsg. R. Bielfeldt. Heidelberg: Universitätsverlag Winter, 2014. S. 163-194.

Hölscher 2017 - Hölscher F. Die Macht der Gottheit im Bild: Archäologische Studien zur griechischen Götterstatue. Heidelberg: Verlag Antike, 2017.

Hölscher 2019 - Hölscher T. Krieg und Kunst im antiken Griechenland und Rom: vier Triebkräfte kriegerischer Gewalt: Heldentum, Identität, Herrschaft, Ideologie. Berlin: Walter de Gruyter, 2019.

Mangold 2000 - Mangold M. Kassandra in Athen. Die Eroberung Trojas auf attischen Vasenbildern. Berlin: Dietrich Reimer Verlag, 2000. 
Muth 2008 - Muth S. Gewalt im Bild. Das Phänomen der medialen Gewalt im Athen des 6. und 5. Jahrhunderts v. Chr. Berlin: Walter de Gruyter, 2008.

Pipili 1997 - Pipili M. Ilioupersis // Lexicon Iconographicum Mythologiae Classicae. Bd. 8. Zürich; Düsseldorf: Artemis Verlag, 1997. S. 650-657.

Recke 2002 - Recke M. Gewalt und Leid. Das Bild des Krieges bei den Athenern im 6. und 5. Jahrhundert v. Chr. Istanbul: Ege Yayınları, 2002.

Rösler 1987 - Rösler W. Der Frevel des Ajas in der 'Iliupersis' // Zeitschrift für Papyrologie und Epigraphik. Bd. 69. S. 1-8.

Scardino 2007 - Scardino C. Gestaltung und Funktion der Reden bei Herodot und Thukydides. Berlin: Walter de Gruyter, 2007.

Sciarma 2012 - Sciarma A. I delitti religiosi nell'immaginario Greco: Mito e immagini. Napoli: Loffredo, 2012.

Simon, Hirmer 1976 - Simon E., Hirmer M. Die griechischen Vasen. München: Hirmer Verlag, 1976.

Touchefeu 1981 - Touchefeu O. Aias II // Lexicon Iconographicum Mythologiae Classicae. Bd. 1. Zürich; Düsseldorf: Artemis Verlag, 1981. S. 336-351.

Touchefeu 1984 - Touchefeu O. Astyanax I // Lexicon Iconographicum Mythologiae Classicae. Bd. 2. Zürich; Düsseldorf: Artemis Verlag, 1984. S. 929-937.

Trampedach 2005 - Trampedach K. Hierosylia. Gewalt in Heiligtümern // Die andere Seite der Klassik: Gewalt im 5. und 4. Jahrhundert v. Chr. / Hrsg. G. Fischer, S. Moraw. Stuttgart: Franz Steiner Verlag, 2005. S. 143-165.

Vlachogianni 2018 - Vlachogianni E. Neoptolemos: Zu einer Reliefbasis aus Athen - ein Denkmal der Kulturpolitik des Lykurg // Archäologischer Anzeiger. 2018. Hbd. 2. S. 1-28.

West 2013 - West M. L. The epic cycle: A commentary on the lost Troy epics. Oxford: Oxford Univ. Press, 2013.

\section{References}

Anderson, M. J. (1997). The fall of Troy in early Greek poetry and art. Oxford: Clarendon Press.

Fisher, N. R. E. (1992). Hybris: A study in the values of honour and shame in Ancient Greece. Warminster: Aris \& Phillips.

Gehrke, H.-J. (2010). Der zwiespältige Held. In M. Meyer, R. von den Hoff (Eds.). Helden wie sie: Übermensch - Vorbild - Kultfigur in der griechischen Antike. Beiträge zu einem altertumswissenschaftlichen Kolloquium in Wien, 2.-4. Februar 2007, 39-54. Freiburg: Rombach. (In German).

Giuliani, L. (2003). Bild und Mythos. Geschichte der Bilderzählung in der griechischen Kunst. München: C. H. Beck. (In German).

Giuliani, L. (2010). Helden-Hybris. In M. Meyer, R. von den Hoff (Eds.). Helden wie sie. Übermensch - Vorbild - Kultfigur in der griechischen Antike. Beiträge zu einem altertumswissenschaftlichen Kolloquium in Wien, 2.-4. Februar 2007, 203-214. Freiburg: Rombach. (In German).

Giuliani, L. Heilmeyer, W.-D. (Eds.) (1991). Euphronios der Maler: eine Ausstellung in der Sonderausstellungshalle der Staatliche Museen Preussischer Kulturbesitz, BerlinDahlem 20.3.-26.5.1991. Milan: Fabbri. (In German).

Hedreen, G. M. (2001). Capturing Troy: The narrative functions of landscape in archaic and early classical Greek art. Ann Arbor: Univ. of Michigan Press.

Hoff, R. von den (2005). “Achill, das Vieh?” Zur Problematisierung transgressiver Gewalt in klassischen Vasenbildern. In G. Fischer, S. Moraw (Eds.). Die andere Seite der Klassik. Gewalt im 5. und 4. Jahrhundert v. Chr., 225-246. Stuttgart: Franz Steiner Verlag. (In German). 
Hölscher, F. (2017). Die Macht der Gottheit im Bild: Archäologische Studien zur griechischen Götterstatue. Heidelberg: Verlag Antike. (In German).

Hölscher, T. (2014). Im Bild noch lebendiger als in Wirklichkeit: Bildwerke, Lebewesen und Dinge im antiken Griechenland. In R. Bielfeldt (Ed.). Ding und Mensch in der Antike. Gegenwart und Vergegenwärtigung, 163-194. Heidelberg: Universitätsverlag Winter. (In German).

Hölscher, T. (2019). Krieg und Kunst im antiken Griechenland und Rom: vier Triebkräfte kriegerischer Gewalt: Heldentum, Identität, Herrschaft, Ideologie. Münchner Vorlesungen zu antiken Welten. Berlin: Walter de Gruyter. (In German).

Hölscher, U. (Trans.) (2002). Pindar. Siegeslieder. München: C. H. Beck. (In German).

Mangold, M. (2000). Kassandra in Athen. Die Eroberung Trojas auf attischen Vasenbildern. Berlin: Dietrich Reimer Verlag. (In German).

Muth, S. (2008). Gewalt im Bild. Das Phänomen der medialen Gewalt im Athen des 6. und 5. Jahrhunderts v. Chr. Berlin: Walter de Gruyter. (In German).

Pipili, M. (1997). Ilioupersis. In Lexicon Iconographicum Mythologiae Classicae (Vol. 8), 650657. Zürich: Artemis Verlag.

Recke, M. (2002). Gewalt und Leid. Das Bild des Krieges bei den Athenern im 6. und 5. Jahrhundert v. Chr. Istanbul: Ege Yayınlar1. (In German).

Rösler, W. (1987). Der Frevel des Ajas in der 'Iliupersis'. Zeitschrift für Papyrologie und Epigraphik, 69, 1-8. (In German).

Scardino, C. (2007). Gestaltung und Funktion der Reden bei Herodot und Thukydides. Berlin: Walter de Gruyter. (In German).

Sciarma, A. (2012). I delitti religiosi nell'immaginario Greco: Mito e immagini. Napoli: Loffredo. (In Italian).

Simon, E., Hirmer, M. (1976). Die griechischen Vasen. München: Hirmer Verlag. (In German).

Touchefeu, O. (1981). Aias II. In Lexicon Iconographicum Mythologiae Classicae (Vol. 1), 336-351. Zürich; Düsseldorf: Artemis Verlag.

Touchefeu, O. (1984). Astyanax I. In Lexicon Iconographicum Mythologiae Classicae (Vol. 2), 929-937. Zürich; Düsseldorf: Artemis Verlag.

Trampedach, K. (2005). Hierosylia. Gewalt in Heiligtümern. In G. Fischer, S. Moraw (Eds.). Die andere Seite der Klassik: Gewalt im 5. und 4. Jahrhundert v. Chr., 143-165. Stuttgart: Franz Steiner Verlag. (In German).

Vlachogianni, E. (2018). Neoptolemos: Zu einer Reliefbasis aus Athen - ein Denkmal der Kulturpolitik des Lykurg. Archäologischer Anzeiger, 2018(2), 1-28. (In German).

West, M. L. (2013). The epic cycle: A commentary on the lost Troy epics. Oxford: Oxford Univ. Press.

\section{Информация об авторе}

\section{Фернанда Хёльшер}

доктор наук, Lecturer Emerita, Констанский университет

Германия, Констани

FernandeHoelscher@gmx.de

$$
* * *
$$

\section{Information about the author}

\section{Fernande Hölscher}

Dr., Lecturer Emerita,

University of Konstanz

Germany, Konstanz

FernandeHoelscher@gmx.de 